\title{
An update on ozone profile trends for the period 2000 to 2016
}

Wolfgang Steinbrecht ${ }^{1}$, Lucien Froidevaux ${ }^{2}$, Ryan Fuller ${ }^{2}$, Ray Wang ${ }^{3}$, John Anderson ${ }^{4}$, Chris Roth ${ }^{5}$, Adam Bourassa $^{5}$, Doug Degenstein ${ }^{5}$, Robert Damadeo ${ }^{6}$, Joe Zawodny ${ }^{6}$, Stacey Frith $^{7,8}$, Richard McPeters ${ }^{7}$, Pawan Bhartia $^{7}$, Jeannette Wild ${ }^{9}, 10$, Craig Long ${ }^{9}$, Sean Davis ${ }^{11,12}$, Karen Rosenlof ${ }^{11}$, Viktoria Sofieva ${ }^{13}$,

Kaley Walker ${ }^{14}$, Nabiz Rahpoe ${ }^{15}$, Alexei Rozanov ${ }^{15}$, Mark Weber ${ }^{15}$, Alexandra Laeng ${ }^{16}$, Thomas von Clarmann ${ }^{16}$, Gabriele Stiller ${ }^{16}$, Natalya Kramarova ${ }^{7,8}$, Sophie Godin-Beekmann ${ }^{17}$, Thierry Leblanc ${ }^{18}$, Richard Querel ${ }^{19}$, Daan Swart $^{20}$, Ian Boyd ${ }^{21}$, Klemens Hocke ${ }^{22}$, Niklaus Kämpfer ${ }^{22}$, Eliane Maillard Barras ${ }^{23}$, Lorena Moreira ${ }^{22}$, Gerald Nedoluha $^{24}$, Corinne Vigouroux ${ }^{25}$, Thomas Blumenstock ${ }^{16}$, Matthias Schneider ${ }^{16}$, Omaira García ${ }^{26}$, Nicholas Jones $^{27}$, Emmanuel Mahieu ${ }^{28}$, Dan Smale ${ }^{19}$, Michael Kotkamp ${ }^{19}$, John Robinson ${ }^{19}$, Irina Petropavlovskikh ${ }^{29,12}$, Neil Harris ${ }^{30}$, Birgit Hassler ${ }^{31}$, Daan Hubert ${ }^{25}$, and Fiona Tummon ${ }^{32}$

${ }^{1}$ Deutscher Wetterdienst, Hohenpeissenberg, Germany

${ }^{2}$ Jet Propulsion Laboratory, California Institute of Technology, Pasadena, CA, USA

${ }^{3}$ School of Earth and Atmospheric Sciences, Georgia Institute of Technology, Atlanta, GA, USA

${ }^{4}$ Department of Atmospheric and Planetary Sciences, Hampton University, Hampton, VA, USA

${ }^{5}$ Institute of Space and Atmospheric Studies, University of Saskatchewan, Saskatoon, Canada

${ }^{6}$ NASA Langley Research Center, Hampton, VA, USA

${ }^{7}$ NASA Goddard Space Flight Center, Silver Spring, MD, USA

${ }^{8}$ Science Systems and Applications Inc., Lanham, MD, USA

${ }^{9}$ NOAA/NWS/NCEP/Climate Prediction Center, College Park, MD, USA

${ }^{10}$ Innovim LLC, Greenbelt, MD, USA

${ }^{11}$ Chemical Sciences Division, NOAA ESRL, Boulder, CO, USA

${ }^{12}$ CIRES, University of Colorado, Boulder, CO, USA

${ }^{13}$ Finnish Meteorological Institute, Helsinki, Finland

${ }^{14}$ Department of Physics, University of Toronto, Toronto, Canada

${ }^{15}$ Institute for Environmental Physics, University of Bremen, Bremen, Germany

${ }^{16}$ Karlsruhe Institute of Technology, Institute of Meteorology and Climate Research, Karlsruhe, Germany

${ }^{17}$ Centre National de la Recherche Scientifique, Université de Versailles Saint-Quentin-en-Yvelines, Guyancourt, France

${ }^{18}$ Jet Propulsion Laboratory, California Institute of Technology, Wrightwood, CA, USA

${ }^{19}$ National Institute of Water and Atmospheric Research (NIWA), Lauder, New Zealand

${ }^{20}$ National Institute for Public Health and the Environment (RIVM), Bilthoven, the Netherlands

${ }^{21}$ BC Scientific Consulting LLC, Stony Brook, NY, USA

${ }^{22}$ Institute of Applied Physics and Oeschger Centre for Climate Change Research, University of Bern, Bern, Switzerland

${ }^{23}$ MeteoSwiss, Payerne, Switzerland

${ }^{24}$ Naval Research Laboratory, Washington, D.C., USA

${ }^{25}$ Royal Belgian Institute for Space Aeronomy (BIRA-IASB), Brussels, Belgium

${ }^{26}$ Izaña Atmospheric Research Centre (IARC), Agencia Estatal de Meteorología (AEMET), Santa Cruz de Tenerife, Spain

${ }^{27}$ School of Chemistry, University of Wollongong, Wollongong, Australia

${ }^{28}$ Institute of Astrophysics and Geophysics, University of Liège, Liège, Belgium

${ }^{29}$ Climate Monitoring Division, NOAA ESRL, Boulder, CO, USA

${ }^{30}$ Centre for Atmospheric Informatics and Emissions Technology, Cranfield University, Cranfield, UK

${ }^{31}$ Bodeker Scientific, Alexandra, New Zealand

${ }^{32}$ ETH Zürich, Zürich, Switzerland

Correspondence to: Wolfgang Steinbrecht (wolfgang.steinbrecht@dwd.de) 
Received: 27 April 2017 - Discussion started: 2 May 2017

Revised: 11 August 2017 - Accepted: 14 August 2017 - Published: 11 September 2017

\begin{abstract}
Ozone profile trends over the period 2000 to 2016 from several merged satellite ozone data sets and from ground-based data measured by four techniques at stations of the Network for the Detection of Atmospheric Composition Change indicate significant ozone increases in the upper stratosphere, between 35 and $48 \mathrm{~km}$ altitude ( 5 and $1 \mathrm{hPa}$ ). Near $2 \mathrm{hPa}(42 \mathrm{~km})$, ozone has been increasing by about $1.5 \%$ per decade in the tropics $\left(20^{\circ} \mathrm{S}\right.$ to $\left.20^{\circ} \mathrm{N}\right)$, and by 2 to $2.5 \%$ per decade in the 35 to $60^{\circ}$ latitude bands of both hemispheres. At levels below $35 \mathrm{~km}$ ( $5 \mathrm{hPa}$ ), 2000 to 2016 ozone trends are smaller and not statistically significant. The observed trend profiles are consistent with expectations from chemistry climate model simulations. This study confirms positive trends of upper stratospheric ozone already reported, e.g., in the WMO/UNEP Ozone Assessment 2014 or by Harris et al. (2015). Compared to those studies, three to four additional years of observations, updated and improved data sets with reduced drift, and the fact that nearly all individual data sets indicate ozone increase in the upper stratosphere, all give enhanced confidence. Uncertainties have been reduced, for example for the trend near $2 \mathrm{hPa}$ in the 35 to $60^{\circ}$ latitude bands from about $\pm 5 \%(2 \sigma)$ in Harris et al. (2015) to less than $\pm 2 \%(2 \sigma)$. Nevertheless, a thorough analysis of possible drifts and differences between various data sources is still required, as is a detailed attribution of the observed increases to declining ozone-depleting substances and to stratospheric cooling. Ongoing quality observations from multiple independent platforms are key for verifying that recovery of the ozone layer continues as expected.
\end{abstract}

\section{Introduction}

Depletion of the stratospheric ozone layer by anthropogenic chlorine and bromine from ozone-depleting substances (ODSs) has been a worldwide concern since the 1970s (Stolarski and Cicerone, 1974; Molina and Rowland, 1974). Initially, studies predicted the largest ozone losses for the upper stratosphere, at about $42 \mathrm{~km}$ or $2 \mathrm{hPa}$ (Crutzen, 1974). For the total column of ozone only moderate losses were predicted. Public perception of the situation changed dramatically with the discovery of the Antarctic ozone hole (Chubachi, 1984; Farman et al., 1985). The ozone hole is characterized by large ozone depletion throughout the lower stratosphere, which is due to heterogeneous reactions on the surface of polar stratospheric clouds (Solomon, 1999). These important reactions had not been known and not been included in the early predictions. The large springtime ozone losses over an entire continent were a huge surprise. The world's nations reacted to mounting evidence that ODSs were harming the vital ozone layer, first by signing the International Vienna Convention for the Protection of the Ozone Layer in 1985, then by implementing the 1987 Montreal Protocol and its later amendments. Thanks to these agreements, the worldwide production and consumption of ODSs have been eliminated almost completely since the early 1990s (WMO, 2007).

The Montreal Protocol has been very successful. The concentration of ODSs in the atmosphere has been declining since the mid-1990s in the troposphere, and since the late 1990s also in the stratosphere (WMO, 2011). Scientific assessments of the state of the ozone layer have shown that the ozone layer is responding: the decline of ozone in the upper stratosphere stopped around 2000 (Newchurch et al., 2003; WMO, 2007). Total ozone columns have also stabilized (WMO, 2011, 2014). Given the current slow decline of ODS concentrations, we now expect ozone to increase accordingly in the stratosphere. However, this small increase is not easily separated from concurrent variability and changes in temperature, atmospheric circulation, and solar ultraviolet flux (Jonsson et al., 2004; Reinsel et al., 2005; WMO, 2007, 2011).

The last WMO/UNEP ozone assessment (WMO, 2014), therefore, concluded that statistically significant increases of ozone had been observed only in the upper stratosphere (around $42 \mathrm{~km}$ or $2 \mathrm{hPa}$ ), but not at lower levels, and not for total ozone columns. About half of the increase in the upper stratosphere was attributed to declining ODSs, the other half to declining temperature. This stratospheric cooling is caused by increasing $\mathrm{CO}_{2}$ (Jonsson et al., 2004; Randel et al., 2016). Low temperature enhances ozone in the upper stratosphere, by slowing gas-phase destruction cycles and making ozone production more efficient.

Studies published after WMO (2014) have confirmed the tendency of ozone to increase in the upper stratosphere, but they also pointed out that instrument drifts and drift uncertainties might be larger than the 1 to $2 \%$ per decade assumed in WMO (2014). Hubert et al. (2016), for example, reported drifts and drift uncertainties between satellite and groundbased data exceeding $5 \%$ per decade for some instruments, and less than $2 \%$ per decade only for a few instruments. Harris et al. (2015) found larger differences between trends from some data sets, exceeding $6 \%$ per decade. Based on these larger differences and the larger drift uncertainty estimates (Hubert et al., 2016), Harris et al. (2015) concluded that upward trends of upper stratospheric ozone might not be statistically different from zero.

The purpose of the present paper is to follow up on these studies, but with 3 to 4 more years of data, and with im- 
Table 1. Merged satellite data sets used in the present study. The URLs serve as an entry point only, and do not always provide the newest and most complete data set used here. See text for references.

\begin{tabular}{|c|c|c|c|c|}
\hline Name & Version(s) & Start & End & URL \\
\hline SBUV-NASA & v8.60MOD & May $1970^{\mathrm{a}}$ & December 2016 & https://acd-ext.gsfc.nasa.gov/Data_services/merged/ \\
\hline SBUV-NOAA & v8.60 & November 1978 & December 2016 & ftp://ftp.cpc.ncep.noaa.gov/SBUV_CDR/ \\
\hline GOZCARDS & $\mathrm{v} 2.20$ & February $1979^{b}$ & December 2016 & https://gozcards.jpl.nasa.gov/ \\
\hline SWOOSH & v2.6 & October 1984 & December 2016 & https://www.esrl.noaa.gov/csd/groups/csd8/swoosh/ \\
\hline SAGE II-OSIRIS (+ OMPS) $)^{\mathrm{c}, \mathrm{d}}$ & v7.0, v5.10 (and 2-D $\left.{ }^{\mathrm{d}}\right)$ & October 1984 & December 2016 & http://osirus.usask.ca/ \\
\hline SAGE II-Ozone_CCI-OMPS ${ }^{\mathrm{d}}$ & v7.0, v2, 2-D ${ }^{\mathrm{d}}$ & October 1984 & December 2016 & http://www.esa-ozone-cci.org/ \\
\hline SAGE II-MIPAS-OMPS & v7.0, KIT v7, v2 ${ }^{\mathrm{e}}$ & October $1984^{\mathrm{f}}$ & March 2017 & https://www.imk-asf.kit.edu/english/304_2857.php \\
\hline
\end{tabular}

Table 2. Stations and instruments used in the present study. Lidar, microwave, and FTIR data are from the Network for the Detection of Atmospheric Composition Change (NDACC) and are originally available at http://www.ndacc.org. Umkehr data were provided by I. Petropavlovskikh.

\begin{tabular}{llllll}
\hline Name & Latitude & Longitude & Instrument & Start & End \\
\hline Fairbanks & $64.8^{\circ} \mathrm{N}$ & $147.9^{\circ} \mathrm{W}$ & Umkehr & March 1994 & September 2015 \\
Hohenpeissenberg & $47.8^{\circ} \mathrm{N}$ & $11.0^{\circ} \mathrm{E}$ & lidar & September 1987 & December 2016 \\
Bern & $46.9^{\circ} \mathrm{N}$ & $7.5^{\circ} \mathrm{E}$ & microwave & November 1994 & December 2016 \\
Payerne & $46.8^{\circ} \mathrm{N}$ & $7.0^{\circ} \mathrm{E}$ & microwave & January 2000 & December 2016 \\
Arosa & $46.8^{\circ} \mathrm{N}$ & $9.7^{\circ} \mathrm{E}$ & Umkehr & January 1956 & December 2015 \\
Jungfraujoch & $46.6^{\circ} \mathrm{N}$ & $8.0^{\circ} \mathrm{E}$ & FTIR & May 1995 & November 2016 \\
Haute Provence & $43.9^{\circ} \mathrm{N}$ & $5.7^{\circ} \mathrm{E}$ & lidar & July 1985 & October 2016 \\
Haute Provence & $43.9^{\circ} \mathrm{N}$ & $5.7^{\circ} \mathrm{E}$ & Umkehr & January 1984 & November 2015 \\
Boulder & $40.0^{\circ} \mathrm{N}$ & $105.3^{\circ} \mathrm{W}$ & Umkehr & January 1984 & December 2015 \\
Table Mountain & $34.4^{\circ} \mathrm{N}$ & $117.7^{\circ} \mathrm{W}$ & lidar & February 1988 & September 2016 \\
Izaña & $28.3^{\circ} \mathrm{N}$ & $16.5^{\circ} \mathrm{W}$ & FTIR & March 1999 & October 2016 \\
Mauna Loa & $19.5^{\circ} \mathrm{N}$ & $155.6^{\circ} \mathrm{W}$ & lidar & July 1993 & September 2016 \\
Mauna Loa & $19.5^{\circ} \mathrm{N}$ & $155.6^{\circ} \mathrm{W}$ & microwave & July 1995 & May 2015 \\
Mauna Loa & $19.5^{\circ} \mathrm{N}$ & $155.6^{\circ} \mathrm{W}$ & Umkehr & January 1984 & December 2015 \\
Wollongong & $34.4^{\circ} \mathrm{S}$ & $150.9^{\circ} \mathrm{E}$ & FTIR & May 1996 & November 2016 \\
Perth & $34.7^{\circ} \mathrm{S}$ & $138.6^{\circ} \mathrm{E}$ & Umkehr & January 1987 & December 2015 \\
Lauder & $45.0^{\circ} \mathrm{S}$ & $169.7^{\circ} \mathrm{E}$ & microwave & October 1992 & October 2016 \\
Lauder & $45.0^{\circ} \mathrm{S}$ & $169.7^{\circ} \mathrm{E}$ & lidar & November 1994 & December 2016 \\
Lauder & $45.0^{\circ} \mathrm{S}$ & $169.7^{\circ} \mathrm{E}$ & FTIR & October 2001 & December 2016 \\
Lauder & $45.0^{\circ} \mathrm{S}$ & $169.7^{\circ} \mathrm{E}$ & Umkehr & February 1987 & December 2015 \\
\hline
\end{tabular}

proved and additional data sets. Here we present initial results. A more comprehensive investigation of instrumental and merging uncertainties, and of uncertainties for different regression analyses is under way in the Long-term Ozone Trends and Uncertainties in the Stratosphere initiative (LOTUS), an activity of the Stratosphere-troposphere Processes And their Role in Climate project (SPARC) of the World Climate Research Programme (WCRP); see http: //www.sparc-climate.org/activities/ozone-trends/.

\section{Ozone profile data records}

The determination of ozone trends requires homogeneous data records that extend over several decades, because not only ozone variations associated with the quasi-biennial oscillation must be quantified well, but also the slow variations associated with the 11-year solar cycle (Newchurch et al., 2003; Steinbrecht et al., 2004). Available long-term records of ozone profile data start before 1990 and extend to the present (see also Tegtmeier et al., 2013; Hassler et al., 2014; Tummon et al., 2015). Tables 1 and 2 summarize the merged satellite records and ground-based stations used in the present study.

\subsection{Data sources}

The nadir-viewing Solar Backscatter Ultraviolet (SBUV) instruments on NASA and NOAA satellites have measured ozone profiles continuously since late 1978, covering the 


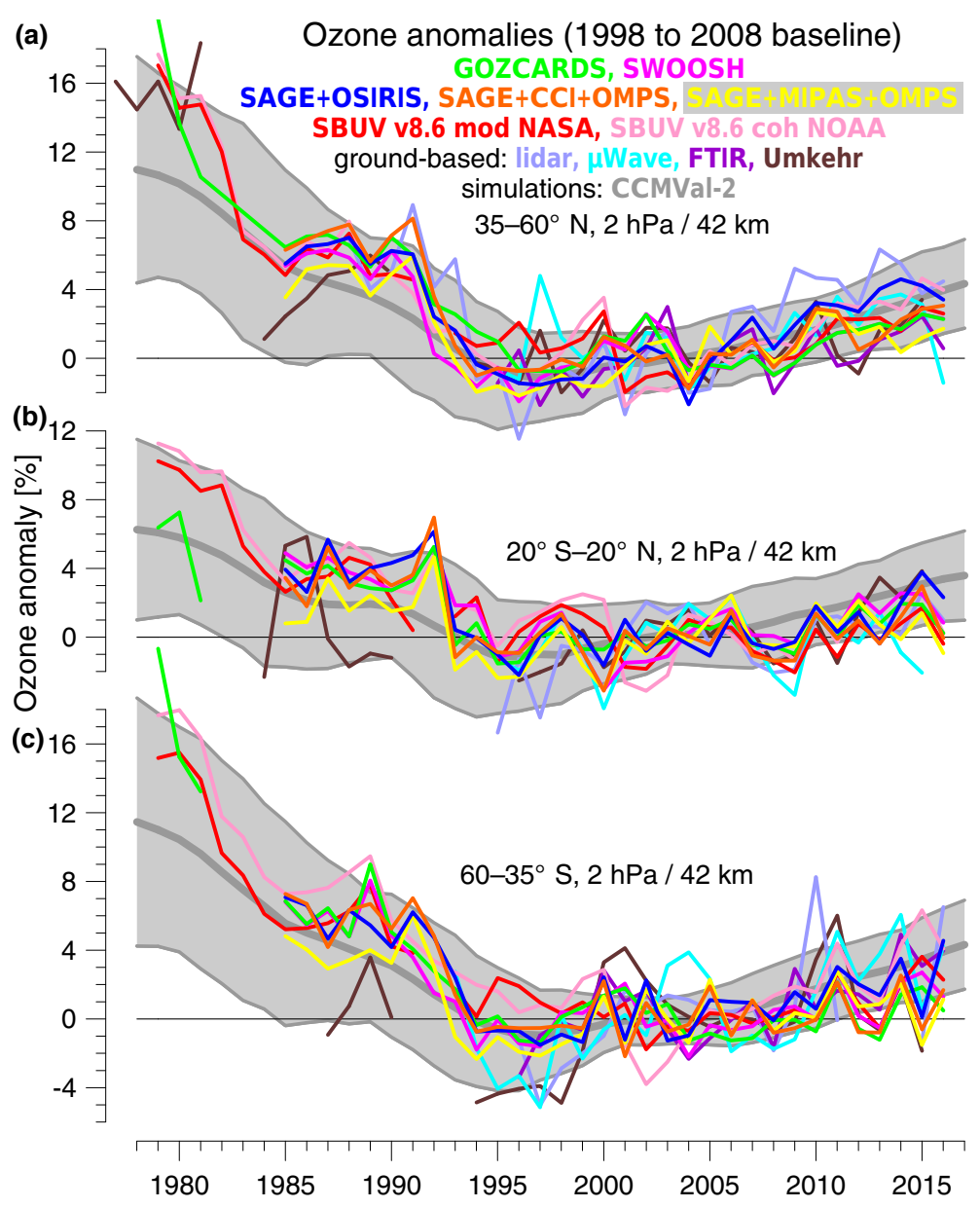

Figure 1. Annual mean ozone anomalies near $2 \mathrm{hPa}$ or $42 \mathrm{~km}$, as recorded by merged satellite data sets and ground-based stations. Anomalies are referenced to the 1998 to 2008 climatological annual cycle of each individual data set, and are averaged over the indicated zonal bands. Stations close to a zonal band are also included, i.e., NDACC lidar data from Table Mountain at $34.4^{\circ}$ N, NDACC FTIR data from Izaña at $28.3^{\circ} \mathrm{N}$ and Wollongong at $34.4^{\circ} \mathrm{S}$, and Umkehr data from Perth at $34.7^{\circ} \mathrm{S}$ are included in the respective midlatitude bands. Due to contamination by volcanic aerosol after the eruptions of El Chichon and Mt. Pinatubo, Umkehr data are not used for the years 1982, 1983, and 1991 to 1993, and SBUV-NASA data are not available for 1992. Grey lines show the multimodel mean ozone anomalies from CCMVal-2 simulations (Eyring et al., 2010), with the grey shading giving the \pm 2 SD envelope. Mean and SD are taken over all models (except outliers) and within a 25 -month sliding window.

sunlit part of the globe, but with only coarse altitude resolution of 10 to $15 \mathrm{~km}$ (McPeters et al., 2013). Orbit drifts, differences between individual instruments, instrument degradation, and some other problems require careful assessment, when generating a long-term data set from these measurements. Currently two SBUV-based data sets (Version 8.60) are available: the merged SBUV MOD (release 6) ozone data set generated by NASA (Frith et al., 2014), termed SBUVNASA in the following, and the "coherent" SBUV data set generated by NOAA (Wild et al., 2016), termed SBUVNOAA in the following. The two data sets rely on the same SBUV instruments, but differ in the approach taken for merging their individual records (see also Frith et al., 2017).

Ozone profiles with higher vertical resolution (about $2 \mathrm{~km}$ ), but also with sparser coverage, were provided by the satellite-borne Stratospheric Aerosol and Gas Experiments (SAGE I and SAGE II) and the Halogen Occultation Experiment (HALOE). These instruments measured in solar occultation geometry from 1979 to about 1982 (SAGE I), from late 1984 to 2005 (SAGE II), and from 1991 to 2005 (HALOE); see, e.g., Damadeo et al. (2013, 2014) and Remsberg (2008). Since 2002, the Optical Spectrograph and InfraRed Imaging System (OSIRIS) measures ozone profiles from ultraviolet light scattered in limb geometry (McLinden et al., 2012). SAGE II and OSIRIS ozone profiles have been combined by Bourassa et al. (2014) to produce a long-term data set, which has subsequently been improved by correcting for a tangent altitude drift of the OSIRIS instrument (Bourassa et al., 2017). Optionally, this data set also includes ozone profiles from the limb-viewing instrument of the Ozone Map- 
ping Profiler Suite (OMPS), which has operated since early 2012 (e.g., Flynn et al., 2014).

Using microwave emissions in limb geometry, the Microwave Limb Sounder (MLS) on the Aura satellite has been measuring many stratospheric trace gases since 2004, including ozone profiles with dense spatial sampling and a vertical resolution of 2.5 to $3 \mathrm{~km}$ in the stratosphere (Waters et al., 2006). SAGE, HALOE, and MLS ozone profiles have been combined in the Global OZone Chemistry And Related trace gas Data records for the Stratosphere (GOZCARDS, Froidevaux et al., 2015, newer version 2.20 used here) and in the Stratospheric Water and Ozone Satellite Homogenized data set (SWOOSH, Davis et al., 2016). GOZCARDS (v2.20) and SWOOSH (v2.6) are very similar (compare Fig. 1). Both rely to a large degree on the ozone records from SAGE II (1984 to 2005, version 7) and Aura-MLS (2004 to present, version 4.2). Both adjust ozone values from other satellites to those from SAGE II. GOZCARDS additionally uses SAGE I (version 5.9_rev) to extend the ozone record back to 1979.

For the period from August 2002 to April 2012, ozone profiles were also measured by the SCIAMACHY (SCanning Imaging Absorption spectroMeter for Atmospheric CHartographY), GOMOS (Global Ozone Monitoring by Occultation of Stars) and MIPAS (Michelson Interferometer for Passive Atmospheric Sounding) instruments on board the European ENVISAT satellite. Positive ozone trends have been reported in the upper stratosphere for each of these instruments (Gebhardt et al., 2014; Kyrölä et al., 2013; Eckert et al., 2014). Unfortunately, ENVISAT failed in April 2012, and measurements ceased. The ESA Climate Change Initiative has generated a harmonized ozone profile data set (Sofieva et al., 2013; Rahpoe et al., 2015) from the ENVISAT instruments, the SMR (Sub-Millimeter Radiometer) microwave instrument, the OSIRIS instrument, and ACEFTS (Atmospheric Chemistry Experiment Fourier Transform Spectrometer; see Bernath, 2017). This ESA CCI or Ozone CCI ozone profile record has recently been updated and extended, with SAGE II ozone profiles back to 1984, and with OMPS ozone profiles (2-D retrieval from U. Saskatoon) from 2012 to the present (SAGE-CCI-OMPS; see Sofieva et al., 2017). Another new merged data set, following previous work by Laeng et al. (2017), combines the MIPAS (Fischer et al., 2008) ozone profile record (KIT/IMK processing) with the records from SAGE II and OMPS (NASA v2 retrieval). Because of short or lacking overlap periods, this SAGEMIPAS-OMPS record relies on ACE-FTS as a transfer standard for matching MIPAS high spectral resolution mode data (July 2002 to March 2004) to MIPAS low spectral resolution mode data (January 2005 to April 2012), and for matching the latter to OMPS data (after February 2012).

While satellites provide near global coverage, the limited lifetimes of most satellite instruments makes the construction of consistent long-term records difficult, as indicated above. Long-term consistency, therefore, might be more easily achieved by ground-based measurements, albeit at the cost of only local coverage. Ground-based instruments have provided some of the longest available records for ozone trend analysis (e.g., Zanis et al., 2006; Nair et al., 2013). Therefore, the ground-based stations in Table 2 are used as an independent source for ozone trends in the present study. The longest ground-based ozone profile records for the upper stratosphere come from Dobson spectrometers operated in "Umkehr" mode (Petropavlovskikh et al., 2005, 2011). Umkehr ozone profiles have coarse altitude resolutions of about $10 \mathrm{~km}$. Long-term ground-based measurements of ozone in the upper stratosphere are also available from the Network for the Detection of Atmospheric Composition Change (NDACC, http://www.ndacc.org, Kurylo et al., 2016). These measurements started in the late 1980s and 1990s, using differential absorption lidars, microwave radiometers (Steinbrecht et al., 2009), and Fourier transform infrared spectrometers (FTIRs, Vigouroux et al., 2015). FTIR ozone profiles have coarse altitude resolution (8 to $15 \mathrm{~km}$ ) and resolve only three layers in the stratosphere. Altitude resolution for the microwave radiometers is also 8 to $15 \mathrm{~km}$. Lidars provide altitude resolution between $1 \mathrm{~km}$ (below $30 \mathrm{~km}$ ) and $10 \mathrm{~km}$ (above $45 \mathrm{~km}$ ).

A comprehensive intercomparison of limb-viewing satellite instruments with ground-based NDACC ozone sondes and lidars by Hubert et al. (2016) indicates that SAGE II and Aura-MLS, the primary instruments in many of the merged records, are very stable. If drifts exist, they are smaller than $\pm 2 \%$ per decade in the 20 to $40 \mathrm{~km}$ region, and not statistically significant. Below $20 \mathrm{~km}$ and above $45 \mathrm{~km}$ uncertainties become larger, because of larger geophysical variation in the compared altitude ranges and because of increasing measurement errors; see also Tegtmeier et al. (2013). Note that in Hubert et al. (2016), the OSIRIS V5.07 ozone data did exhibit a significant drift, up to $8 \%$ per decade near $40 \mathrm{~km}$, which is also apparent in Harris et al. (2015). This drift has been corrected in the revised and updated OSIRIS V5.10 data set used here (Bourassa et al., 2017). Drifts of most SBUV instruments are less than 3 to $5 \%$ per decade, and are not statistically significant (Kramarova et al., 2013). Similarly, Rahpoe et al. (2015) report that drifts of several limb-viewing instruments including ACE-FTS, MIPAS, and OSIRIS are typically less than $3 \%$ per decade (even for older processing versions) and are not statistically significant. For the current study, newer data sets with reduced drifts were available (especially OSIRIS), and older data sets with apparent large drifts were not used (SAGE-GOMOS).

Table 3 compares data sets and trend periods used here, in WMO (2014), and in Harris et al. (2015). In addition to using 3 more years of data, the main difference between the present study and WMO (2014) is the use of four more satellite data sets: SBUV-NOAA, SWOOSH, SAGEOSIRIS, and SAGE-MIPAS-OMPS. OSIRIS and MIPAS (as well as SCIAMACHY, GOMOS, and SMR) were included in the HARMOZ/Ozone_CCI merged data set used in WMO (2014), which is replaced here by the new SAGE- 
Table 3. Comparison between principal data sets, trend periods, and regression method used in the present study, in Harris et al. (2015), and in WMO (2014). Here only major changes in data sets are indicated. Boldface indicates the most relevant differences.

\begin{tabular}{|c|c|c|c|}
\hline & This study & Harris et al. (2015) & WMO (2014) \\
\hline SBUV-NASA & used & used & used \\
\hline SBUV-NOAA & used & used & not used \\
\hline GOZCARDS & used & old version & used \\
\hline SWOOSH & used & old version & not used \\
\hline Ozone_CCI & new version & not used & old version $^{\mathrm{a}}$ \\
\hline SAGE-OSIRIS & new version ${ }^{b}$ & old version $^{\mathrm{c}}$ & not used \\
\hline SAGE-GOMOS & not used & old version ${ }^{c}$ & not used \\
\hline SAGE-MIPAS-OMPS & used & not available & not available \\
\hline Ground-based & used $^{\mathrm{d}}$ & used $^{\mathrm{d}}$ & used $^{\mathrm{e}}$ \\
\hline Trend period & 2000 to 2016 & 1998 to 2012 & 2000 to 2013 \\
\hline Regression method & two steps & hockey-stick & two steps \\
\hline
\end{tabular}

${ }^{a}$ Called HARMOZ. ${ }^{b}$ Drift-corrected OSIRIS data. ${ }^{c}$ OSIRIS and GOMOS data had significant drifts

(Tegtmeier et al., 2013; Harris et al., 2015; Hubert et al., 2016). ${ }^{\mathrm{d}}$ Ground-based trends as independent

verification, but not included in average trend. ${ }^{\mathrm{e}}$ Ground-based trends (weighted) included in average trend.

Ozone_CCI-OMPS data set. The most important differences between this study and Harris et al. (2015) are the different trend periods, the use of the new and improved Ozone_CCI, SAGE-OSIRIS (now drift-corrected) data sets, and the omission of the anomalous SAGE-GOMOS data set. The latter two data sets provided quite different trend estimates from each other, and from other data sets (compare Fig. 6 of Harris et al., 2015).

\subsection{Time series}

Figure 1 shows annual mean ozone anomalies from the different satellite and ground-based data sets, averaged over three latitude bands, and for a level near $2 \mathrm{hPa}$ or $42 \mathrm{~km}$. Anomalies are relative to the 1998 to 2008 climatology of each individual data set. The period 1998 to 2008 was chosen as the reference because ozone values were fairly constant over this period, and many instruments provide data for a substantial fraction of the period: SAGE II and HALOE until late 2005, ENVISAT instruments since late 2002, and Aura-MLS since August 2004. All data sets show clear ozone declines until the late 1990s and generally increasing ozone over the 2000 to 2016 period, especially at midlatitudes. This observed evolution generally confirms expectations from model simulations by Chemistry Climate Models within their Validation-2 initiative (CCMVal-2, Eyring et al., 2010). Grey lines and shading in Fig. 1 give the CCMVal2 multimodel mean and \pm 2 SD envelope, obtained over all models (except outliers) and a 25 month sliding window. The simulations attribute the ozone decline until the late 1990s to increasing ODS loading and predict positive ozone trends due to declining ODS loading since around 2000. In the simulations, the ozone increase is enhanced by overall cooling of the stratosphere due to increasing greenhouse gases over the entire 1978 to 2016 period (see also Jonsson et al., 2004; Randel et al., 2016).
All observational data sets show similar fluctuations from year to year, usually within 1 or $2 \%$ of each other. They also indicate similar long-term tendencies, usually within $\pm 2 \%$ per decade of each other, and are comparable to the CCMVal2 simulations. Generally, the station data show larger variations than the zonal means from the satellite data. This is not surprising, given the sparser temporal sampling of most ground-based data (lidar, Umkehr, and FTIR all require clear sky). Also, the low density of stations will generally result in more variability compared to the smoother wide-band zonal means from the satellite records.

\section{Multiple linear regression}

Multiple linear regression (MLR) has become a standard method for deriving ozone trends (Bojkov et al., 1990; Reinsel et al., 2002; Newchurch et al., 2003; Chehade et al., 2014). MLR can be applied to monthly mean ozone anomaly time series $\mathrm{dO}_{3}(i)$ of many months $i$. The anomalies are obtained by referencing the monthly mean $\mathrm{O}_{3}(i)$ to the climatological mean for each calendar month $\mathrm{O}_{3}$, Clim $(i \bmod 12)$.

$\mathrm{dO}_{3}(i)=\frac{\mathrm{O}_{3}(i)-\mathrm{O}_{3, \operatorname{Clim}}(i \bmod 12)}{\mathrm{O}_{3, \operatorname{Clim}}(i \bmod 12)}$

MLR attempts to reconstruct the observed anomalies as a linear combination of prescribed predictors $P_{j}(i)$, which account for known ozone variations, and residual noise $\epsilon(i)$.

$\mathrm{dO}_{3}(i)=c_{0}+\sum_{j=1}^{n} c_{j} \times P_{j}(i)+\epsilon(i)$

Here our set of predictors $P_{j}$ include a linear trend, a change of the trend in January 1997 (hockey stick, reflecting the increase of ozone depleting substances until the late 

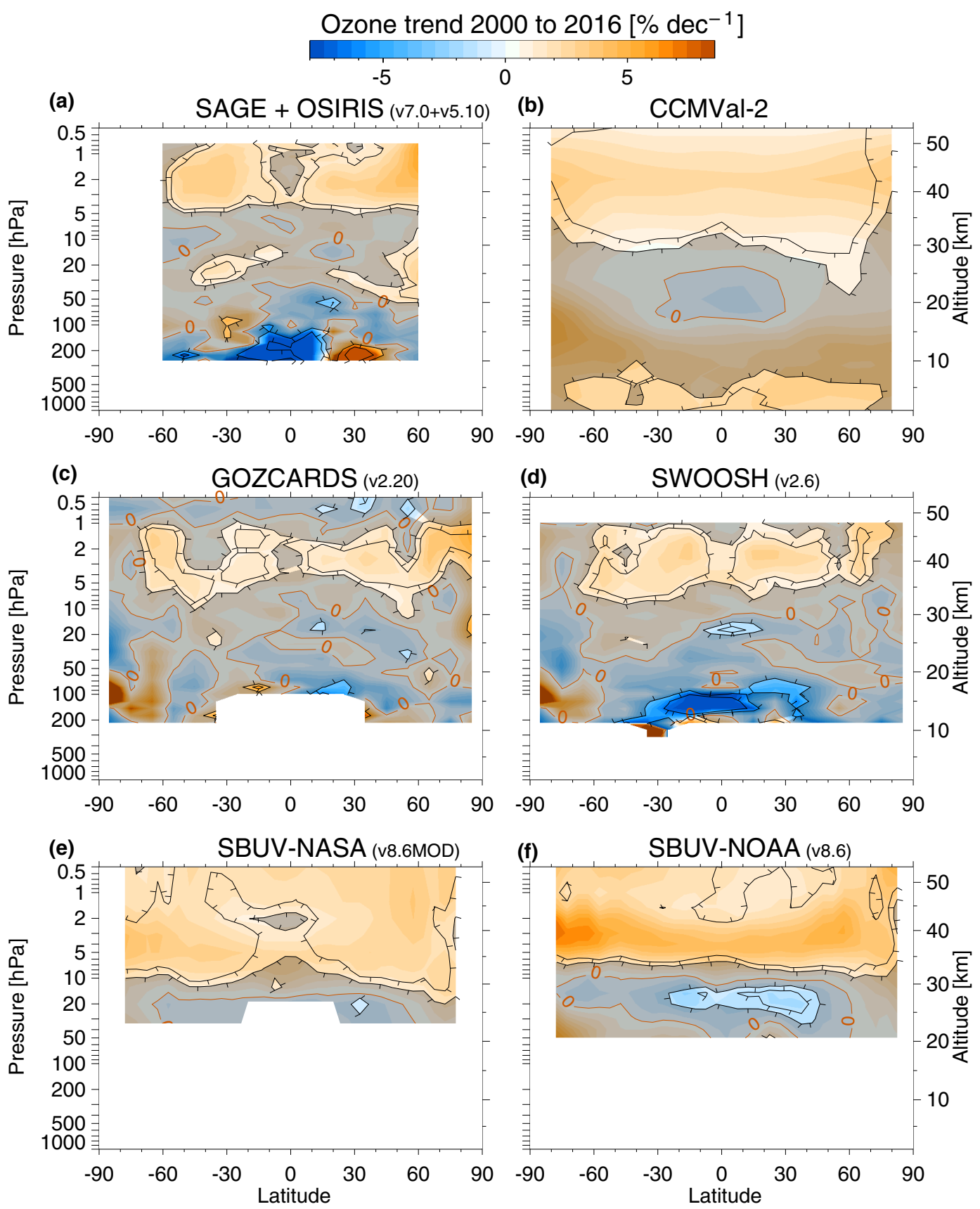

Figure 2. Latitude pressure cross section of 2000 to 2016 ozone trends TR obtained by 2-step multiple linear regression (see text). Panel (b) is for model simulations from the CCMVal-2 initiative. The other panels are for merged satellite data sets. The colour scale gives trend magnitude TR. Shading and isolines give the ratio of trend to trend uncertainty, $|\mathrm{TR}| / \sigma$. Grey shading, in regions where $|\mathrm{TR}| \leq 2 \sigma$, indicates that trends are not significant at the $95 \%$ confidence level. The next isoline is at $|\mathrm{TR}| / \sigma=3$.

1990s, and their decline since), six proxies for the quasibiennial oscillation $(\mathrm{QBO}$, equatorial zonal winds at 30 and $10 \mathrm{hPa}$, plus their modulations by sine and cosine with 12 month (annual) period), and a proxy for the 11-year solar cycle, as in Reinsel et al. (2002). Like WMO (2014) or Harris et al. (2015), the present study also includes a proxy for stratospheric aerosol loading and for El Niño/La Niña, which is most relevant for the tropical lower stratosphere (e.g., Oman et al., 2013). Table 4 summarizes the proxies used and their sources. Other studies may include further proxies for weather patterns and meridional ozone transports, such as circulation indices or eddy heat flux (Steinbrecht et al., 2001; Reinsel et al., 2005), but this was not done here. The coefficients $c_{j}$ are obtained by least squares fitting of the residuals, 


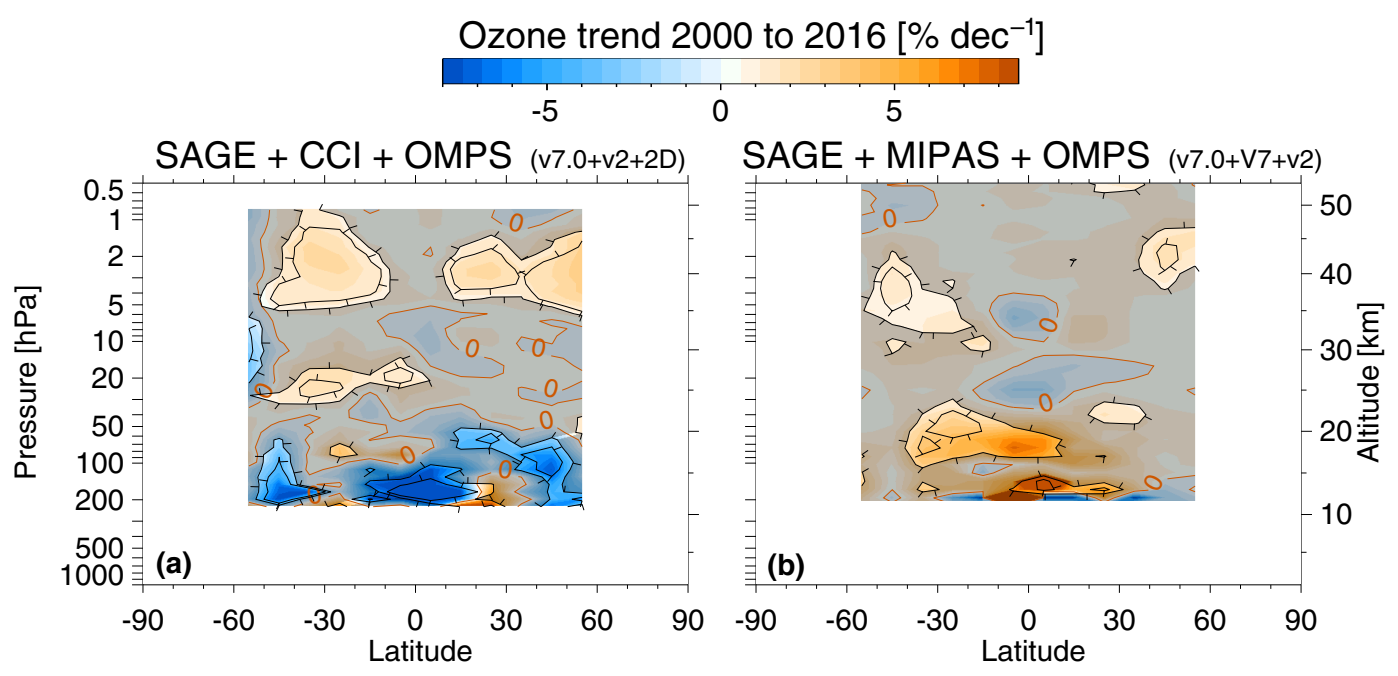

Figure 3. Same as Fig. 2, but showing the 2000 to 2016 ozone trends for the merged SAGE-ESA Ozone CCI-OMPS, and SAGE-MIPASOMPS data sets. The SAGE-ESA Ozone CCI-OMPS data set uses the OMPS 2-D retrieval from U. Saskatoon. The SAGE-MIPAS-OMPS data set uses the OMPS v2 retrieval from NASA.

i.e., minimization of $\sum_{i} \epsilon^{2}(i)$. Typically, the residuals $\epsilon(i)$ are of the order of 1 to $10 \%$, large enough to cover fit errors and measurement errors for each monthly mean.

If realistic uncertainties $\Delta \mathrm{O}_{3}(i)$ are available for each monthly mean, the anomalies can be weighted by their inverse squared uncertainty (high weight for low uncertainty), and the uncertainties $\Delta \mathrm{O}_{3}(i)$ can be used to estimate the uncertainty $\Delta c_{j}$ of the fitted $c_{j}$. However, in many cases reliable uncertainties are not available for monthly means, because it is difficult to account correctly for all error terms, and for autocorrelation and covariance of the individual measurement errors (e.g., Toohey and von Clarmann, 2013; Damadeo et al., 2014). A time-invariant bias, for example, might be included in the monthly mean uncertainty, but it would be irrelevant for the long-term trend. So in many studies, including Reinsel et al. (2005), WMO (2014), Harris et al. (2015) and this study, the pragmatic approach is to use the SD of the fit residuals $\epsilon(i)$ for estimating the uncertainties $\Delta c_{j}$ of the fitted coefficients.

Strictly, the uncertainties from the MLR assume that the predictors are orthogonal, and that the residuals $\epsilon(i)$ are uncorrelated white noise. In practice, the predictors above are orthogonal enough (cross-correlations less than 0.3 for the long periods considered), and first-order autocorrelation in the residuals is small $(|\mathrm{AC}| \ll 0.3)$. Still, to correct for firstorder autocorrelation AC (Reinsel et al., 2002), the $\Delta c_{j}$ are multiplied here by $\sqrt{(1+\mathrm{AC}) /(1-\mathrm{AC})}$. Neglecting higher orders of autocorrelation might result in slightly underestimated uncertainties (Vyushin et al., 2007).

One problem with the "hockey stick" fit is that the slope of the declining trend and the time of the turning point have an influence on the slope of the second part of the hockey stick (Reinsel et al., 2002). To reduce this problem, a second step was introduced in WMO (2014), and this approach is also used here. First, Eq. (2) is fitted for the entire long time series, e.g., from 1978 to 2016. The QBO, solar cycle, aerosol, and El Niño effects resulting from this first fit are then subtracted from the ozone anomalies $\mathrm{dO}_{3}(i)$. This provides time series of ozone residuals $\mathrm{O}_{3 \text {,res }}(i)$, which have most of the variability associated with QBO, solar cycle, aerosol, and El Niño removed, but which still contain the long-term trend component, substantial remaining variability and the $\epsilon(i)$. The use of the entire 30- to 40-year-long time series in the first step is particularly important for a good estimate of the 11-year solar cycle effect, which cannot be estimated well with shorter records. Then, in a second step, a simple linear trend is fitted to the $\mathrm{O}_{3 \text {,res }}(i)$. This trend can be fitted over any desired period, in this case the period 2000 to 2016 . The second fit is not constrained by a hockey stick assumption, and has full freedom to react to the remaining ozone variations over the desired period.

\section{Ozone profile trends}

\subsection{Trends for individual data sets}

Figures 2 and 3 present the latitude-pressure cross sections of 2000 to 2016 ozone trends, TR, (and uncertainties $\sigma$ ) obtained using the two-step method from the previous section for the satellite-based data sets from Sect. 2. In addition, the top right panel shows corresponding trends for the multimodel mean of the CCMVal-2 simulations. For the simulations, trend uncertainty was derived from the SD of individual monthly anomalies from the multimodel mean (shaded envelope in Fig. 1). For the observations, trend uncertainty was derived from the fit residuals, as mentioned in Sect. 2. 
Although the two approaches differ, fit residuals for the observations and SD of the simulated monthly anomalies have similar magnitude (compare Fig. 1), and the resulting trend uncertainties are similar. The magnitude of all trends is represented by the colour scale. Grey shading indicates regions where trends are not statistically significant $(95 \%$ confidence level, $|\mathrm{TR}| \leq 2 \sigma)$. All satellite data sets show significant ozone increases in the extratropical upper stratosphere, above 10 to $5 \mathrm{hPa}$ (30 to $35 \mathrm{~km}$ ). Some show significant ozone increases also in the tropical upper stratosphere. At levels between 50 and $10 \mathrm{hPa}(20$ and $30 \mathrm{~km})$, trends are generally not significant, except for islands of significant trends near 20 or $50 \mathrm{hPa}$ in some data sets, mostly in the Southern Hemisphere. Most data sets (but not SAGE-MIPAS-OMPS) also show significant ozone decline in the tropical lowermost stratosphere below $100 \mathrm{hPa}(16 \mathrm{~km})$. However, satellite measurements in this region can have large uncertainties and need very careful consideration, both in tropics and extratropics (see also Tegtmeier et al., 2013).

The simulations (in the top right panel of Fig. 2) confirm that significant trends should be expected only in the upper stratosphere, between 10 and $0.5 \mathrm{hPa}$ (30 to $55 \mathrm{~km}$ ), especially in the extratropics. Exactly there, the observed data sets give significant increasing trends. Both magnitude - between 1 and $5 \%$ per decade - and latitudinal pattern - smaller increases in the tropics, larger increases at higher latitudes - are consistent between the satellite data sets and the simulations.

Figures 2 and 3, therefore, provide substantial observational evidence for significant ozone increases in the upper stratosphere, consistent with model simulations based on declining ODSs and decreasing temperatures in the upper stratosphere. Comparison of Figs. 2 and 3 with Figs. 2-10 of WMO (2014) shows that the addition of 3 more years of data, as well as improved and additional data sets, have not changed the overall picture very much. Comparable patterns, but slightly smaller increases are also reported in Fig. 5 of Harris et al. (2015) for the 1998 to 2012 period (but only between $60^{\circ} \mathrm{S}$ and $60^{\circ} \mathrm{N}$ ). Compared to that figure, the SAGE-OSIRIS trends here have changed considerably because of improved data (see also Bourassa et al., 2017). The SWOOSH trends have increased in magnitude. The SAGEGOMOS data, which had shown large, and probably unrealistic ozone decline polewards of $40^{\circ}$ latitude in Fig. 5 of Harris et al. (2015) are not used here.

A specific look at zonal mean trends from all satellite and ground-based data sets is given in Fig. 4. The basis for these trend calculations is zonal band anomaly time series as in Fig. 1. In Fig. 4, almost all individual data sets show increasing ozone between 5 and $1 \mathrm{hPa}$, with trends between 0 and $4 \%$ per decade. For the 5 and $2 \mathrm{hPa}$ levels, the plotted $\pm 2 \sigma$ uncertainty bars (from the MLR) indicate that most individual trends are statistically significant (95\% confidence level). Between 50 and $10 \mathrm{hPa}(22$ and $30 \mathrm{~km})$, most data sets indicate small and non-significant trends. In the lowermost stratosphere, between 100 and $50 \mathrm{hPa}(16$ and $22 \mathrm{~km})$, sev- eral data sets report ozone decreases, but these are generally not statistically significant. Differences between data sets are larger as well. Overall, Fig. 4 confirms significant ozone increases in the upper stratosphere from nearly all satellite and ground-based data sets, whereas ozone trends at lower levels are generally smaller and not significant.

\subsection{From individual data set trends to the average trend}

It is useful to obtain an average ozone trend profile from all individual trends. In WMO (2014) this was done by a weighted mean of all individual ground-based and satellite trends TR $(i)$. Each individual trend was weighted with its inverse squared uncertainty $(1 / \sigma(i))^{2}$, so more uncertain trends have less weight. Individual uncertainties $\sigma(i)$ came from the regression (as in Sect. 3) and also included a 1 or $2 \%$ per decade drift uncertainty ( $2 \sigma$, depending on the instrument) added in quadrature. This standard weighted mean approach (SWM) was also one of the approaches used in Harris et al. (2015), but with much larger drift uncertainties ( 4 or $6 \%$ per decade, $2 \sigma$ ). This resulted in larger overall uncertainty and in non-significant trends in Harris et al. (2015) compared to WMO (2014).

One problem with the standard weighted mean is that its uncertainty does not depend on the spread of the individual trends (because of Gaussian error propagation). Therefore, Harris et al. (2015) also considered the joint distribution approach $(J)$. There, the uncertainty of the mean trend is essentially given by the SD $\sigma$ between the individual trends (which includes possible instrument drifts), divided by $\sqrt{n}$, where $n$ is the number of data sets. Strictly, $n$ should be the number of statistically independent data sets. However, since most merged data sets use the same SBUV, SAGE, MLS, or OMPS instruments, these data sets are not independent. Also, trend calculation by multiple linear regression uses the same approach and the same proxies for all data sets, which may further reduce independence between the individual trend estimates.

To be compatible with Harris et al. (2015), where standard weighted mean approach with large drift uncertainties and joint distribution approach gave similar average trends ( 1 to $3 \%$ per decade in the upper stratosphere) and similar uncertainties ( 2 to $6 \%$ per decade, $2 \sigma$ ), it was decided to also use the joint distribution approach for the average trend in the present study. Table 5 summarizes the methods used in the different studies to arrive at an average trend and its uncertainty.

Figure 5 shows the joint distribution average trends (black lines), obtained here by averaging the seven satellite data sets (GOZCARDS, SWOOSH, SAGE-OSIRIS, SAGE-CCI-OMPS, SAGE-MIPAS-OMPS, SBUV-NASA, and SBUV-NOAA). All were given the same weight, but SBUV data were used only at levels above $40 \mathrm{hPa}(23 \mathrm{~km})$, because the lower SBUV layers mix stratospheric and tro- 
Table 4. Proxy time series used for the multiple linear regression in Eq. (2) in this study.

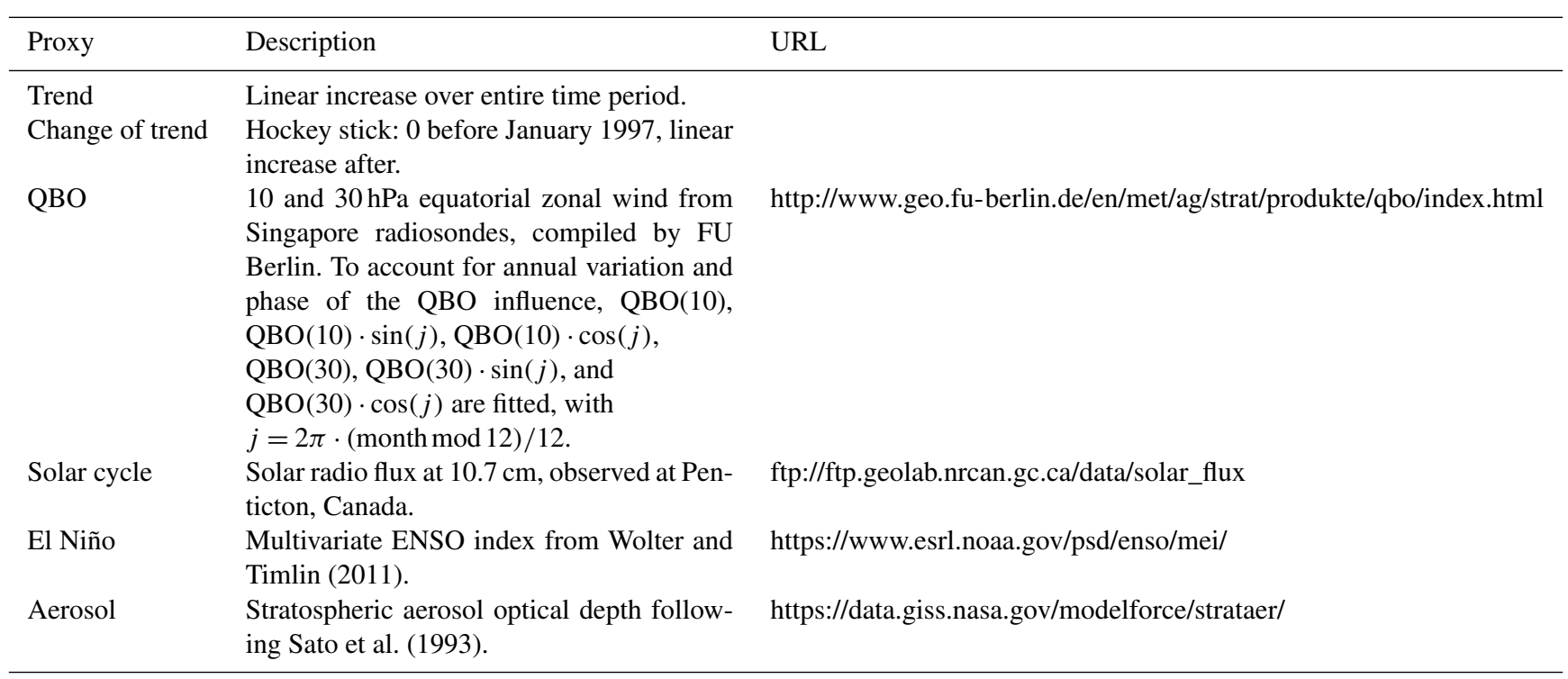

Table 5. Approaches taken to obtain the average trend and its uncertainty estimate in the present study, in Harris et al. (2015) and in WMO (2014). Boldface indicates the approach used for the results plotted in Fig. 5.

\begin{tabular}{llll}
\hline & This study & Harris et al. (2015) & WMO (2014) \\
\hline Standard weighted mean $($ SWM) & not used & used & used \\
Assumed drift uncertainty $(2 \sigma)$ & not used & 4 or $6 \%$ decade & $\mathbf{1}$ or $\mathbf{2} \%$ decade \\
Number of data sets in SWM & - & $6^{\text {a }}$ & $\mathbf{9}^{\text {b }}$ \\
Joint distribution $(J)$ & used & used & not used \\
Number of data sets in $J$ & $7^{\text {a }}$ & $\mathbf{6}^{\text {a }}$ & - \\
\hline
\end{tabular}

${ }^{a}$ Only satellite-based data sets included in average. ${ }^{b}$ Ground-based data sets were also included. Ozone sondes not used at levels higher than $10 \mathrm{hPa} / 31 \mathrm{~km}$.

pospheric ozone information due to their very wide averaging kernels (see also Kramarova et al., 2013). Ground-based data were not included in the average trends, because of their sparser sampling (which would require small weights) and also to be compatible with Harris et al. (2015). Nevertheless, the ground-based trends, shown in Fig. 4, provide important independent verification of the satellite-based trends.

The (joint distribution) uncertainty bars in Fig. 5 (black error bars) give the full $\pm 2 \sigma$ SDs between all seven satellitebased trend estimates. Using these uncertainty bars in the figure assumes only one independent realization $(n=1)$, and should give a very conservative uncertainty estimate for the mean trend, TR. Even with this conservative uncertainty estimate, significant increasing trends $(|\mathrm{TR}| \geq 2 \sigma)$ appear in Fig. 5 for the $2 \mathrm{hPa}$ level in the tropics and at northern midlatitudes. Table 6 gives the same trend results, but now bold letters indicate trends, TR, which are significant with $95 \%$ confidence ( $|\mathrm{TR}| \geq 2 \sigma / \sqrt{n}$ ), assuming $n=3$ independent realizations, or $n=2$ below $40 \mathrm{hPa}$. In this less conservative case, significant increasing trends appear nearly everywhere above $10 \mathrm{hPa}(30 \mathrm{~km})$. As mentioned above, trends at $70 \mathrm{hPa}$ (and below) differ more between data sets and should be considered with care. See also the large error bars below $50 \mathrm{hPa}$ for the tropical latitudes in Fig. 5.

\subsection{Comparison to previous studies}

For comparison, the yellow lines and shading in Fig. 5 show the average 1998 to 2012 trends and uncertainties from Harris et al. (2015, joint distribution case), and the blue lines give the average 2000 to 2013 trends and error bars from WMO (2014). See Tables 3 and 5 for a summary of the different data sets and approaches. Overall, the updated 2000 to 2016 trend profiles (black lines) agree quite well with Harris et al. (2015) and with WMO (2014), especially when the overlapping error bars are considered. One difference is that the previous negative trend around $5-8 \mathrm{hPa}$ in the tropics is not observed any more. The major difference, however, is the substantially larger uncertainty range reported in Harris et al. (2015) for the upper stratosphere. As mentioned before, it is probably caused by two outlying data sets in Harris et al. (2015): (1) an older version of the SAGE-OSIRIS 
Ozone trend 2000 to 2016

Satellites: SBUV-NASA, -NOAA, GOZCARDS, SWOOSH, SAGE+OSIRIS, SAGE+CCI+OMPS

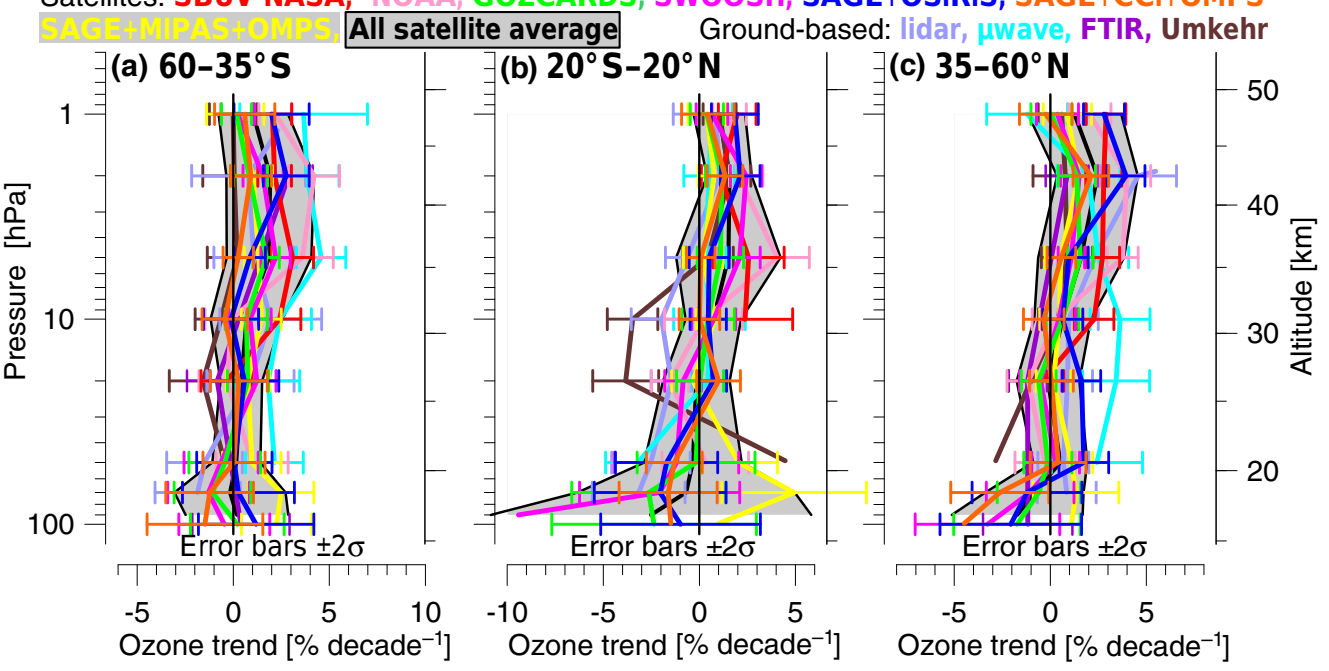

Figure 4. Vertical profiles of 2000 to 2016 ozone trends, obtained by 2-step multiple linear regression (see text), for different merged satellite and ground-based station data sets. Results are for the zonal bands 60 to $35^{\circ} \mathrm{S}$ (a), $20^{\circ} \mathrm{S}$ to $20^{\circ} \mathrm{N}$ (b) and 35 to $60^{\circ} \mathrm{N}$ (c). For the 60 to $35^{\circ} \mathrm{S}$ zonal band, FTIR data from Wollongong $\left(34.4^{\circ} \mathrm{S}\right)$, and Umkehr data from Perth $\left(34.7^{\circ} \mathrm{S}\right)$ are included. For the 35 to $60^{\circ} \mathrm{N}$ band, lidar data from Table Mountain $\left(34.4^{\circ} \mathrm{N}\right)$ and FTIR data from Izaña $\left(28.3^{\circ} \mathrm{N}\right)$ are included. SBUV and Umkehr data are not shown at or below the $50 \mathrm{hPa}$ level. Black lines and grey shading show the average trend and $\pm 2 \sigma$ SDs of the seven satellite-based trends (see also Fig. 5 and text).

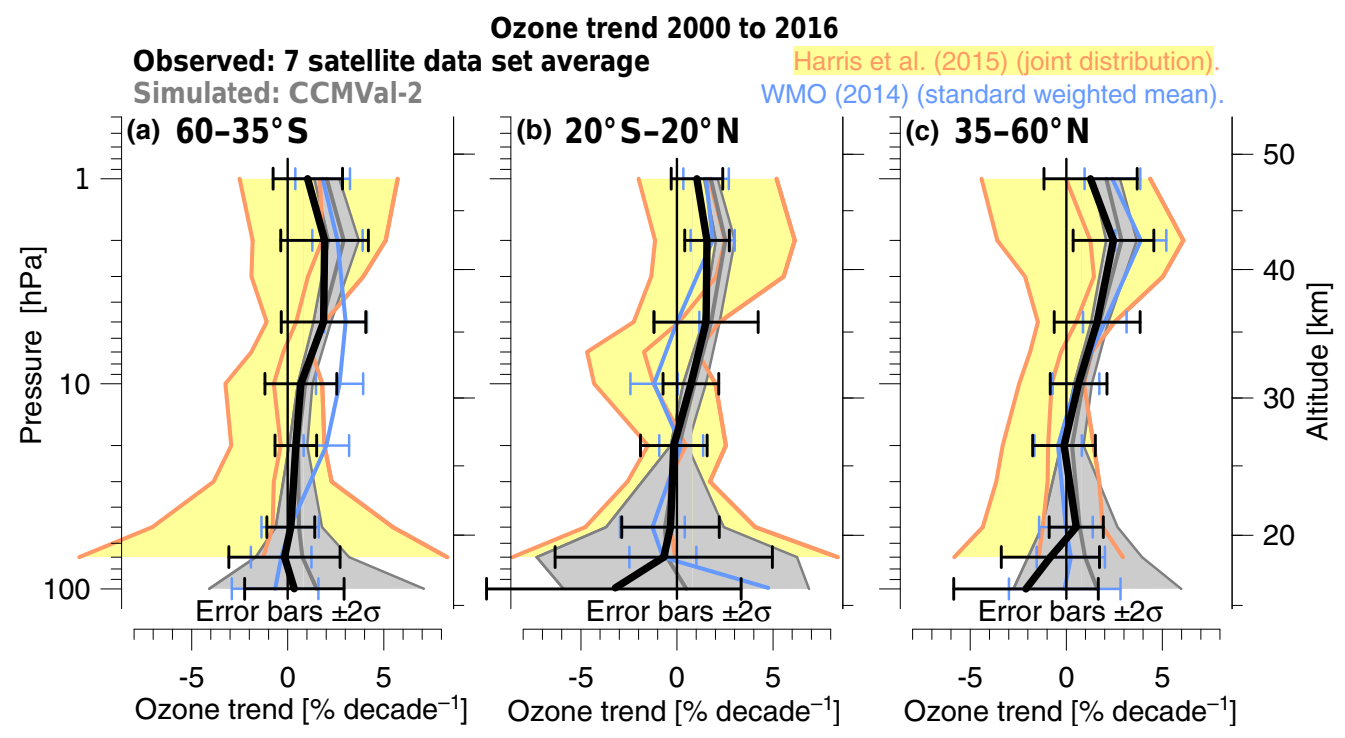

Figure 5. Same as Fig. 4, but giving the average 2000 to 2016 ozone trends (black lines) from seven merged satellite data sets (GOZCARDS, SWOOSH, SAGE-OSIRIS, SAGE-CCI-OMPS(2D), SAGE-MIPAS-OMPS(v2), SBUV-NASA, and SBUV-NOAA). SBUV trends are only used at levels above $40 \mathrm{hPa}(23 \mathrm{~km}$ ). For comparison, the 1998 to 2012 average ozone trend from Harris et al. (2015, yellow lines and shading), and the 2000 to 2013 average ozone trend from WMO 2014 (blue lines) are shown as well. In all cases, uncertainty bars or shading give $\pm 2 \sigma$ uncertainty. For the 2000 to 2016 satellite average ozone trends (black error bars), and trends from Harris et al. (2015, yellow shading) the uncertainty is derived from the $\mathrm{SD} \sigma$ between individual trends in the average (joint distribution case). For the WMO 2014 trends (blue error bars), the uncertainty of the standard weighted mean is given (see text for details). Grey lines and shading give the trend and $\pm 2 \sigma$ uncertainty obtained from multimodel mean and SD of the CCMVal-2 model simulations (see text in Sect. 4.1).

data set, in which the OSIRIS (V5.07) data suffered from a large drift (Hubert et al., 2016; Bourassa et al., 2017). (2) A now outdated SAGE-GOMOS data set, which exhibited unrealistically low/negative trends at latitudes poleward of $45^{\circ}$ (see Fig. 5 of Harris et al., 2015). For levels above $5 \mathrm{hPa}$ $(35 \mathrm{~km})$ and levels below $30 \mathrm{hPa}(25 \mathrm{~km})$, the new and im- 
Table 6. Average 2000 to 2016 ozone profile trends, obtained from individual trends for the GOZCARDS, SWOOSH, SAGE-OSIRIS, SAGE-CCI-OMPS(2D), SAGE-MIPAS-OMPS(v2), SBUV-NASA, and SBUV-NOAA satellite data sets. Given are mean trend TR and SD $1 \sigma$ of the individual trends, in percent per decade. Bold numbers indicate average trends TR larger than $2 \sigma / \sqrt{3} \approx 1.15 \sigma$, i.e., statistically significant values with $95 \%$ confidence, assuming that the seven data sets give three independent realizations of individual trends TR $(i)$. The SBUV-NASA and SBUV-NOAA data sets are used only at levels above $40 \mathrm{hPa}(23 \mathrm{~km})$. Therefore, $2 \sigma / \sqrt{2} \approx 1.41 \sigma$ is applied as threshold for boldface at the 50 and $70 \mathrm{hPa}$ levels.

\begin{tabular}{lrr|rr|rr|r|rr}
\hline Level & \multicolumn{2}{c|}{$60-35^{\circ} \mathrm{S}$} & \multicolumn{2}{|c|}{$20^{\circ} \mathrm{S}-20^{\circ} \mathrm{N}$} & \multicolumn{2}{|c|}{$35-60^{\circ} \mathrm{N}$} & \multicolumn{2}{|c}{$60^{\circ} \mathrm{S}-60^{\circ} \mathrm{N}$} \\
\cline { 2 - 8 }$(\mathrm{hPa})$ & $\mathrm{TR}$ & $1 \sigma$ & $\mathrm{TR}$ & $1 \sigma$ & $\mathrm{TR}$ & $1 \sigma$ & $\mathrm{TR}$ & $1 \sigma$ \\
\hline 1 & $\mathbf{1 . 0}$ & 0.9 & $\mathbf{1 . 0}$ & 0.7 & $\mathbf{1 . 3}$ & 1.2 & $\mathbf{1 . 1}$ & 0.7 \\
2 & $\mathbf{1 . 9}$ & 1.1 & $\mathbf{1 . 6}$ & 0.6 & $\mathbf{2 . 5}$ & 1.1 & $\mathbf{1 . 8}$ & 0.6 \\
5 & $\mathbf{1 . 9}$ & 1.1 & 1.5 & 1.4 & $\mathbf{1 . 6}$ & 1.1 & $\mathbf{1 . 6}$ & 1.2 \\
10 & 0.7 & 0.9 & 0.7 & 0.7 & 0.6 & 0.7 & 0.8 & 0.7 \\
20 & 0.4 & 0.5 & -0.2 & 0.9 & -0.1 & 0.8 & 0.0 & 0.7 \\
50 & 0.2 & 0.6 & -0.3 & 1.3 & 0.5 & 0.7 & 0.0 & 0.8 \\
70 & -0.2 & 1.4 & -0.7 & 2.8 & -0.8 & 1.3 & -0.6 & 1.9 \\
\hline
\end{tabular}

All values are $\%$ per decade.

proved merged satellite data sets, and the additional years, provide substantially smaller trend uncertainties than Harris et al. (2015). In particular, a look at Fig. 4 indicates that individual trends from the merged satellite data sets and the ground-based instruments used here differ, in most cases, by less than 2 or $3 \%$ per decade, at levels above $50 \mathrm{hPa}$. This much better agreement indicates that previously large instrumental drifts and drift uncertainties (around $6 \%$ per decade for some data sets Harris et al., 2015; Hubert et al., 2016) have been reduced substantially since.

Compared to WMO (2014), the current work reports slightly larger uncertainty bars. This is expected, because the standard weighted mean uncertainty used in WMO (2014) did not consider the spread of the individual trends (as mentioned above), and also assumed statistical independence for all the data sets in the average.

The updated trend profiles in Fig. 5 also show excellent agreement with the CCMVal-2 simulations, with virtually no difference at levels above $50 \mathrm{hPa}(20 \mathrm{~km})$. The fact that all individual data sets in Fig. 4 indicate significant increases in the upper stratosphere, reduced uncertainty since Harris et al. (2015), excellent agreement with the CCMVal-2 simulations in Fig. 5, and good agreement with trend results from WMO (2014), gives enhanced confidence that ozone is indeed increasing in the upper stratosphere, and that at least part of that increase is due to declining ODSs.

\section{Conclusions}

New and improved satellite data sets and the addition of several years of data until the end of 2016 improve our confidence that ozone in the upper stratosphere, between 5 and $1 \mathrm{hPa}(35$ to $48 \mathrm{~km})$, has been increasing since 2000 . Between 50 and $10 \mathrm{hPa}(20$ to $30 \mathrm{~km})$ trends are small, and there are no clear indications for increasing (or decreasing) ozone. In the lowermost stratosphere, between 100 and $50 \mathrm{hPa}$ (16 and $20 \mathrm{~km}$ ), there might be an indication for decreasing ozone in the tropics and at northern midlatitudes. However, differences between data sets in this region are larger. Instrumental difficulties and large natural variability require more careful analysis of these possible ozone decreases.

Overall, the updated ozone profile trends are consistent with previous studies, e.g., with WMO (2014) and Harris et al. (2015), but average trend uncertainty in the upper stratosphere is reduced by a factor of two compared to Harris et al. (2015). Ozone increases at the $2 \mathrm{hPa}(42 \mathrm{~km})$ level are statistically significant with more than 90 or $95 \%$ confidence over a wide range of latitudes. In addition, the majority of all individual satellite and ground-based data sets also indicate significant ozone increases at levels above $10 \mathrm{hPa}$.

There are, however, remaining questions, for example regarding the merging of different instrumental records, the quality of the records in the lowermost stratosphere, or on the best methods for trend estimation and their detailed uncertainties. These issues are being addressed in the Long-term Ozone Trends and Uncertainties in the Stratosphere (LOTUS) initiative, which runs under the Stratosphere-troposphere Processes And their Role in Climate project (SPARC) of the World Climate Research Programme (WCRP); see http://www.sparc-climate. org/activities/ozone-trends/. The goals of LOTUS are to further improve the data sets, to better understand all relevant uncertainties, and to achieve a more complete and more precise picture of trends in the stratospheric ozone profile. What is also missing is a thorough quantification and attribution of the contributions from decreasing ozone depleting substances, stratospheric cooling (due to increasing $\mathrm{CO}_{2}$ ), and transport changes to the observed profile trend. While this has been done in modelling studies (e.g. Jonsson et al., 2004; 
WMO, 2014), quantification of these factors on the basis of observations has not been done yet.

The update presented here, however, already gives strong indications that ozone in the upper stratosphere has been increasing over the last 15 years and has begun to recover from manmade ozone-depleting substances. Simulations show that this process will take many more decades. In order to verify that ozone recovery continues as expected, reliable longterm observations from multiple independent platforms will remain crucial for many years to come.

Data availability. The satellite ozone records used in this study are available from the sources given in Table 1. The ground-based data are available from the NDACC data base at www.ndacc.org; see also Table 2 . The proxy time series used for trend analysis are available from the sources given in Table 4.

Author contributions. The paper was written by WS, who also did the trend analysis, and is responsible for the NDACC lidar measurements at Hohenpeissenberg. LF, RF, HJW, and JA contributed the GOZCARDS data set, RPD, JMZ, AB, CR, and DD the SAGEOSIRIS-OMPS data set, SF, RSS, RDMcP, and PKB the SBUVNASA data set and OMPS data, JW and CL the SBUV-NOAA data set, SD and KR the SWOOSH data set, VS, KW, NR, AR, MW and others the SAGE-ESA CCI-OMPS data set, and AL, TvC, GS and NK the SAGE-MIPAS-OMPS data set. NDACC lidar measurements were provided by SGB, TL, RQ, and DPJS. NDACC microwave measurements were given by IB, KH, NK, EM, LM, and GN. CV, TB, MS, OG, NJ, EM, DS, MK, and JR provided the NDACC FTIR data. IP and EMB processed the Umkehr data set. $\mathrm{NRPH}, \mathrm{BH}, \mathrm{DH}$, and FT contributed important input and discussions on trends, data sets, and their uncertainties.

Special issue statement. This article is part of the special issue "Quadrennial Ozone Symposium 2016 - Status and trends of atmospheric ozone (ACP/AMT inter-journal SI)". It is a result of the Quadrennial Ozone Symposium 2016, Edinburgh, United Kingdom, 4-9 September 2016.

Acknowledgements. The authors gratefully acknowledge the extremely important contribution from staff at the stations, who run and fix the ground-based systems, and from the many people involved in the satellite measurements. Funding by national and supranational agencies is also gratefully acknowledged. Some of the data sets were calculated with resources provided by the North-German Supercomputing Alliance (HLRN). The merged SAGE-ESA CCI-OMPS data set has been created in the framework of the ESA Ozone_cci project. OHP NDACC lidar measurements are funded by CNRS and CNES. Work performed at the Jet Propulsion Laboratory, California Institute of Technology, was done under contract with the National Aeronautics and Space Administration. NOAA supports and funds a major part of the Dobson Umkehr measurements, in collaboration with funding and work done by Meteoswiss, Switzerland; NIWA, New Zealand; the Australian Bureau of Meteorology; CNRS, France; and the University of Fairbanks, Alaska. We acknowledge the CCMVal-2 group for providing their model simulations. Fiona Tummon was supported by Swiss National Science Foundation grant number 20FI21_138017. We also thank the two reviewers for their helpful comments.

Edited by: Stefan Reis

Reviewed by: Johannes Staehelin and one anonymous referee

\section{References}

Bernath, P. F.: The Atmospheric Chemistry Experiment (ACE), J. Quant. Spectrosc. Ra., 186, 3-16, https://doi.org/10.1016/j.jqsrt.2016.04.006, 2017.

Bojkov, R., Bishop, L., Hill, W. J., Reinsel, G. C., and Tiao, G. C.: A statistical trend analysis of revised Dobson total ozone data over the Northern Hemisphere, J. Geophys. Res., 95, 9785-9807, https://doi.org/10.1029/JD095iD07p09785, 1990.

Bourassa, A. E., Degenstein, D. A., Randel, W. J., Zawodny, J. M., Kyrölä, E., McLinden, C. A., Sioris, C. E., and Roth, C. Z.: Trends in stratospheric ozone derived from merged SAGE II and Odin-OSIRIS satellite observations, Atmos. Chem. Phys., 14, 6983-6994, https://doi.org/10.5194/acp-14-6983-2014, 2014.

Bourassa, A. E., Roth, C. Z., Zawada, D. J., Rieger, L. A., McLinden, C. A., and Degenstein, D. A.: Drift corrected Odin-OSIRIS ozone product: algorithm and updated stratospheric ozone trends, Atmos. Meas. Tech. Discuss., https://doi.org/10.5194/amt-2017229, in review, 2017.

Chehade, W., Weber, M., and Burrows, J. P.: Total ozone trends and variability during 1979-2012 from merged data sets of various satellites, Atmos. Chem. Phys., 14, 7059-7074, https://doi.org/10.5194/acp-14-7059-2014, 2014.

Chubachi, S.: A Special Ozone Observation at Syowa Station, Antarctica, from February 1982 to January 1983, in: Atmospheric Ozone, edited by: Zerefos, C. S. and Ghazi, A., D. Reidel Publishing Company, Dordrecht, the Netherlands, 285-289, 1984.

Crutzen, P. J.: Estimates of possible future ozone reductions from continued use of fluoro-chloro-methanes (CF2Cl2, CFCl3), Geophys. Res. Lett., 1, 205-208, https://doi.org/10.1029/GL001i005p00205, 1974.

Damadeo, R. P., Zawodny, J. M., Thomason, L. W., and Iyer, N.: SAGE version 7.0 algorithm: application to SAGE II, Atmos. Meas. Tech., 6, 3539-3561, https://doi.org/10.5194/amt-6-35392013, 2013.

Damadeo, R. P., Zawodny, J. M., and Thomason, L. W.: Reevaluation of stratospheric ozone trends from SAGE II data using a simultaneous temporal and spatial analysis, Atmos. Chem. Phys., 14, 13455-13470, https://doi.org/10.5194/acp-14-134552014, 2014.

Davis, S. M., Rosenlof, K. H., Hassler, B., Hurst, D. F., Read, W. G., Vömel, H., Selkirk, H., Fujiwara, M., and Damadeo, R.: The Stratospheric Water and Ozone Satellite Homogenized (SWOOSH) database: a long-term database for climate studies, Earth Syst. Sci. Data, 8, 461-490, https://doi.org/10.5194/essd8-461-2016, 2016. 
Eckert, E., von Clarmann, T., Kiefer, M., Stiller, G. P., Lossow, S., Glatthor, N., Degenstein, D. A., Froidevaux, L., GodinBeekmann, S., Leblanc, T., McDermid, S., Pastel, M., Steinbrecht, W., Swart, D. P. J., Walker, K. A., and Bernath, P. F.: Drift-corrected trends and periodic variations in MIPAS IMK/IAA ozone measurements, Atmos. Chem. Phys., 14, 25712589, https://doi.org/10.5194/acp-14-2571-2014, 2014.

Eyring, V., Cionni, I., Bodeker, G. E., Charlton-Perez, A. J., Kinnison, D. E., Scinocca, J. F., Waugh, D. W., Akiyoshi, H., Bekki, S., Chipperfield, M. P., Dameris, M., Dhomse, S., Frith, S. M., Garny, H., Gettelman, A., Kubin, A., Langematz, U., Mancini, E., Marchand, M., Nakamura, T., Oman, L. D., Pawson, S., Pitari, G., Plummer, D. A., Rozanov, E., Shepherd, T. G., Shibata, K., Tian, W., Braesicke, P., Hardiman, S. C., Lamarque, J. F., Morgenstern, O., Pyle, J. A., Smale, D., and Yamashita, Y.: Multimodel assessment of stratospheric ozone return dates and ozone recovery in CCMVal-2 models, Atmos. Chem. Phys., 10, 94519472, https://doi.org/10.5194/acp-10-9451-2010, 2010.

Farman, J. C., Gardiner, B. G., and Shanklin, J. D.: Large losses of total ozone in Antarctica reveal seasonal $\mathrm{ClO}_{x} / \mathrm{NO}_{x}$ interaction, Nature, 315, 207-210, https://doi.org/10.1038/315207a0, 1985.

Fischer, H., Birk, M., Blom, C., Carli, B., Carlotti, M., von Clarmann, T., Delbouille, L., Dudhia, A., Ehhalt, D., Endemann, M., Flaud, J. M., Gessner, R., Kleinert, A., Koopman, R., Langen, J., López-Puertas, M., Mosner, P., Nett, H., Oelhaf, H., Perron, G., Remedios, J., Ridolfi, M., Stiller, G., and Zander, R.: MIPAS: an instrument for atmospheric and climate research, Atmos. Chem. Phys., 8, 2151-2188, https://doi.org/10.5194/acp-8-21512008, 2008.

Flynn, L., Long, C., Wu, X., Evans, R., Beck, C. T., Petropavlovskikh, I., McConville, G., Yu, W., Zhang, Z., Niu, J., Beach, E., Hao, Y., Pan, C., Sen, B., Novicki, M., Zhou, S., and Seftor, C.: Performance of the Ozone Mapping and Profiler Suite (OMPS) products, J. Geophys. Res., 119, 6181-6195, https://doi.org/10.1002/2013JD020467, 2014.

Frith, S. M., Kramarova, N. A., Stolarski, R. S., McPeters, R. D., Bhartia, P. K., and Labow, G. J.: Recent changes in total column ozone based on the SBUV Version 8.6 Merged Ozone Data Set, J. Geophys. Res., 119, 9735-9751, https://doi.org/10.1002/2014JD021889, 2014.

Frith, S. M., Stolarski, R. S., Kramarova, N. A., and McPeters, R. D.: Estimating Uncertainties in the SBUV Version 8.6 Merged Profile Ozone Dataset, Atmos. Chem. Phys. Discuss., https://doi.org/10.5194/acp-2017-412, in review, 2017.

Froidevaux, L., Anderson, J., Wang, H.-J., Fuller, R. A., Schwartz, M. J., Santee, M. L., Livesey, N. J., Pumphrey, H. C., Bernath, P. F., Russell III, J. M., and McCormick, M. P.: Global OZone Chemistry And Related trace gas Data records for the Stratosphere (GOZCARDS): methodology and sample results with a focus on $\mathrm{HCl}, \mathrm{H}_{2} \mathrm{O}$, and $\mathrm{O}_{3}$, Atmos. Chem. Phys., 15, 1047110507, https://doi.org/10.5194/acp-15-10471-2015, 2015.

Gebhardt, C., Rozanov, A., Hommel, R., Weber, M., Bovensmann, H., Burrows, J. P., Degenstein, D., Froidevaux, L., and Thompson, A. M.: Stratospheric ozone trends and variability as seen by SCIAMACHY from 2002 to 2012, Atmos. Chem. Phys., 14, 831-846, https://doi.org/10.5194/acp-14-831-2014, 2014.

Harris, N. R. P., Hassler, B., Tummon, F., Bodeker, G. E., Hubert, D., Petropavlovskikh, I., Steinbrecht, W., Anderson, J., Bhartia, P. K., Boone, C. D., Bourassa, A., Davis, S. M., Degenstein,
D., Delcloo, A., Frith, S. M., Froidevaux, L., Godin-Beekmann, S., Jones, N., Kurylo, M. J., Kyrölä, E., Laine, M., Leblanc, S. T., Lambert, J.-C., Liley, B., Mahieu, E., Maycock, A., de Mazière, M., Parrish, A., Querel, R., Rosenlof, K. H., Roth, C., Sioris, C., Staehelin, J., Stolarski, R. S., Stübi, R., Tamminen, J., Vigouroux, C., Walker, K. A., Wang, H. J., Wild, J., and Zawodny, J. M.: Past changes in the vertical distribution of ozone - Part 3: Analysis and interpretation of trends, Atmos. Chem. Phys., 15, 9965-9982, https://doi.org/10.5194/acp15-9965-2015, 2015.

Hassler, B., Petropavlovskikh, I., Staehelin, J., August, T., Bhartia, P. K., Clerbaux, C., Degenstein, D., Mazière, M. D., Dinelli, B. M., Dudhia, A., Dufour, G., Frith, S. M., Froidevaux, L., GodinBeekmann, S., Granville, J., Harris, N. R. P., Hoppel, K., Hubert, D., Kasai, Y., Kurylo, M. J., Kyrölä, E., Lambert, J.-C., Levelt, P. F., McElroy, C. T., McPeters, R. D., Munro, R., Nakajima, H., Parrish, A., Raspollini, P., Remsberg, E. E., Rosenlof, K. H., Rozanov, A., Sano, T., Sasano, Y., Shiotani, M., Smit, H. G. J., Stiller, G., Tamminen, J., Tarasick, D. W., Urban, J., van der A, R. J., Veefkind, J. P., Vigouroux, C., von Clarmann, T., von Savigny, C., Walker, K. A., Weber, M., Wild, J., and Zawodny, J. M.: Past changes in the vertical distribution of ozone - Part 1: Measurement techniques, uncertainties and availability, Atmos. Meas. Tech., 7, 1395-1427, https://doi.org/10.5194/amt-7-13952014, 2014.

Hubert, D., Lambert, J.-C., Verhoelst, T., Granville, J., Keppens, A., Baray, J.-L., Bourassa, A. E., Cortesi, U., Degenstein, D. A., Froidevaux, L., Godin-Beekmann, S., Hoppel, K. W., Johnson, B. J., Kyrölä, E., Leblanc, T., Lichtenberg, G., Marchand, M., McElroy, C. T., Murtagh, D., Nakane, H., Portafaix, T., Querel, R., Russell III, J. M., Salvador, J., Smit, H. G. J., Stebel, K., Steinbrecht, W., Strawbridge, K. B., Stübi, R., Swart, D. P. J., Taha, G., Tarasick, D. W., Thompson, A. M., Urban, J., van Gijsel, J. A. E., Van Malderen, R., von der Gathen, P., Walker, K. A., Wolfram, E., and Zawodny, J. M.: Ground-based assessment of the bias and long-term stability of $14 \mathrm{limb}$ and occultation ozone profile data records, Atmos. Meas. Tech., 9, 2497-2534, https://doi.org/10.5194/amt-9-2497-2016, 2016.

Jonsson, A. I., de Grandpré, J., Fomichev, V. I., McConnell, J. C., and Beagley, S. R.: Doubled CO2-induced cooling in the middle atmosphere: photochemical analysis of the ozone radiative feedback, J. Geophys. Res., 109, D24103, https://doi.org/10.1029/2004JD005093, 2004.

Kramarova, N. A., Frith, S. M., Bhartia, P. K., McPeters, R. D., Taylor, S. L., Fisher, B. L., Labow, G. J., and DeLand, M. T.: Validation of ozone monthly zonal mean profiles obtained from the version 8.6 Solar Backscatter Ultraviolet algorithm, Atmos. Chem. Phys., 13, 6887-6905, https://doi.org/10.5194/acp13-6887-2013, 2013.

Kurylo, M. J., Thompson, A. M., and De Mazière, M.: The Network for the detection of atmospheric composition change: 25 years old and going strong, The Earth Observer, 28, 4-15, https:// eospso.gsfc.nasa.gov/earthobserver/sep-oct-2016, 2016.

Kyrölä, E., Laine, M., Sofieva, V., Tamminen, J., Päivärinta, S.M., Tukiainen, S., Zawodny, J., and Thomason, L.: Combined SAGE II-GOMOS ozone profile data set for 1984-2011 and trend analysis of the vertical distribution of ozone, Atmos. Chem. Phys., 13, 10645-10658, https://doi.org/10.5194/acp-13-106452013, 2013. 
Laeng, A., von Clarmann, T., Stiller, G., Dinelli, B. M., Dudhia, A., Raspollini, P., Glatthor, N., Grabowski, U., Sofieva, V., Froidevaux, L., Walker, K. A., and Zehner, C.: Merged ozone profiles from four MIPAS processors, Atmos. Meas. Tech., 10, 15111518, https://doi.org/10.5194/amt-10-1511-2017, 2017.

McLinden, C. A., Bourassa, A. E., Brohede, S., Cooper, M., Degenstein, D. A., Evans, W. J. F., Gattinger, R. L., Haley, C. S., Llewellyn, E. J., Lloyd, N. D., Loewen, P., Martin, R. V., McConnell, J. C., McDade, I. C., Murtagh, D., Rieger, L., von Savigny, C., Sheese, P. E., Sioris, C. E., Solheim, B., and Strong, K.: OSIRIS: a decade of scattered light, B. Am. Meteorol. Soc., 93, 1845-1863, https://doi.org/10.1175/BAMS-D-1100135.1, 2012.

McPeters, R. D., Bhartia, P. K., Haffner, D., Labow, G. J., and Flynn, L.: The version 8.6 SBUV ozone data record: an overview, J. Geophys. Res., 118, 8032-8039, https://doi.org/10.1002/jgrd.50597, 2013.

Molina, M. J. and Rowland, F. S.: Stratospheric sink for chlorofluoromethanes: chlorine atom-catalysed destruction of ozone, Nature, 249, 810-812, https://doi.org/10.1038/249810a0, 1974.

Nair, P. J., Godin-Beekmann, S., Kuttippurath, J., Ancellet, G., Goutail, F., Pazmiño, A., Froidevaux, L., Zawodny, J. M., Evans, R. D., Wang, H. J., Anderson, J., and Pastel, M.: Ozone trends derived from the total column and vertical profiles at a northern mid-latitude station, Atmos. Chem. Phys., 13, 10373-10384, https://doi.org/10.5194/acp-13-10373-2013, 2013.

Newchurch, M. J., Yang, E.-S., Cunnold, D. M., Reinsel, G. C., Zawodny, J. M., and Russell, J. M.: Evidence for slowdown in stratospheric ozone loss: first stage of ozone recovery, J. Geophys. Res., 108, 4507, https://doi.org/10.1029/2003JD003471, 2003.

Oman, L. D., Douglass, A. R., Ziemke, J. R., Rodriguez, J. M., Waugh, D. W., and Nielsen, J. E.: The ozone response to ENSO in Aura satellite measurements and a chemistryclimate simulation, J. Geophys. Res., 118, 965-976, https://doi.org/10.1029/2012JD018546, 2013.

Petropavlovskikh, I., Bhartia, P. K., and DeLuisi, J.: New Umkehr ozone profile retrieval algorithm optimized for climatological studies, Geophys. Res. Lett., 32, L16808, https://doi.org/10.1029/2005GL023323, 2005.

Petropavlovskikh, I., Evans, R., McConville, G., Oltmans, S., Quincy, D., Lantz, K., Disterhoft, P., Stanek, M., and Flynn, L.: Sensitivity of Dobson and Brewer Umkehr ozone profile retrievals to ozone cross-sections and stray light effects, Atmos. Meas. Tech., 4, 1841-1853, https://doi.org/10.5194/amt-4-18412011, 2011.

Rahpoe, N., Weber, M., Rozanov, A. V., Weigel, K., Bovensmann, H., Burrows, J. P., Laeng, A., Stiller, G., von Clarmann, T., Kyrölä, E., Sofieva, V. F., Tamminen, J., Walker, K., Degenstein, D., Bourassa, A. E., Hargreaves, R., Bernath, P., Urban, J., and Murtagh, D. P.: Relative drifts and biases between six ozone limb satellite measurements from the last decade, Atmos. Meas. Tech., 8, 4369-4381, https://doi.org/10.5194/amt-8-4369-2015, 2015.

Randel, W. J., Smith, A. K., Wu, F., Zou, C.-Z., and Qian, H.: Stratospheric temperature trends over 1979-2015 derived from combined SSU, MLS, and SABER satellite observations, J. Climate, 29, 4843-4859, https://doi.org/10.1175/JCLI-D-150629.1, 2016.
Reinsel, G. C., Weatherhead, E., Tiao, G. C., Miller, A. J., Nagatani, R. M., Wuebbles, D. J., and Flynn, L. E.: On detection of turnaround and recovery in trend for ozone, J. Geophys. Res., 107, ACH 1-1-ACH 1-12, https://doi.org/10.1029/2001JD000500, 2002.

Reinsel, G. C., Miller, A. J., Weatherhead, E. C., Flynn, L. E., Nagatani, R. M., Tiao, G. C., and Wuebbles, D. J.: Trend analysis of total ozone data for turnaround and dynamical contributions, J. Geophys. Res., 110, D16306, https://doi.org/10.1029/2004JD004662, 2005.

Remsberg, E. E.: On the response of Halogen Occultation Experiment (HALOE) stratospheric ozone and temperature to the 11-year solar cycle forcing, J. Geophys. Res., 113, D22304, https://doi.org/10.1029/2008JD010189, 2008.

Sato, M., Hansen, J. E., McCormick, M. P., and Pollack, J. B.: Stratospheric aerosol optical depths, 1850-1990, J. Geophys. Res., 98, 22987-22994, https://doi.org/10.1029/93JD02553, 1993.

Sofieva, V. F., Rahpoe, N., Tamminen, J., Kyrölä, E., Kalakoski, N., Weber, M., Rozanov, A., von Savigny, C., Laeng, A., von Clarmann, T., Stiller, G., Lossow, S., Degenstein, D., Bourassa, A., Adams, C., Roth, C., Lloyd, N., Bernath, P., Hargreaves, R. J., Urban, J., Murtagh, D., Hauchecorne, A., Dalaudier, F., van Roozendael, M., Kalb, N., and Zehner, C.: Harmonized dataset of ozone profiles from satellite limb and occultation measurements, Earth Syst. Sci. Data, 5, 349-363, https://doi.org/10.5194/essd5-349-2013, 2013.

Sofieva, V. F., Kyrölä, E., Laine, M., Tamminen, J., Degenstein, D., Bourassa, A., Roth, C., Zawada, D., Weber, M., Rozanov, A., Rahpoe, N., Stiller, G., Laeng, A., von Clarmann, T., Walker, K. A., Sheese, P., Hubert, D., van Roozendael, M., Zehner, C., Damadeo, R., Zawodny, J., Kramarova, N., and Bhartia, P. K.: Merged SAGE II, Ozone_cci and OMPS ozone profiles dataset and evaluation of ozone trends in the stratosphere, Atmos. Chem. Phys. Discuss., https://doi.org/10.5194/acp-2017-598, in review, 2017.

Solomon, S.: Stratospheric ozone depletion: a review of concepts and history, Rev. Geophys., 37, 275-316, https://doi.org/10.1029/1999RG900008, 1999.

Steinbrecht, W., Claude, H., Köhler, U., and Winkler, P.: Interannual changes of total ozone and Northern Hemisphere circulation patterns, Geophys. Res. Lett., 28, 1191-1194, https://doi.org/10.1029/1999GL011173, 2001.

Steinbrecht, W., Claude, H., and Winkler, P.: Reply to comment by D. M. Cunnold et al. on "Enhanced upper stratospheric ozone: sign of recovery or solar cycle effect?", J. Geophys. Res., 109, D14306, https://doi.org/10.1029/2004JD004948, 2004.

Steinbrecht, W., Claude, H., Schönenborn, F., McDermid, I. S., Leblanc, T., Godin-Beekmann, S., Keckhut, P., Hauchecorne, A., Gijsel, J. A. E. V., Swart, D. P. J., Bodeker, G. E., Parrish, A., Boyd, I. S., Kämpfer, N., Hocke, K., Stolarski, R. S., Frith, S. M., Thomason, L. W., Remsberg, E. E., Savigny, C. V., Rozanov, A., and Burrows, J. P.: Ozone and temperature trends in the upper stratosphere at five stations of the Network for the Detection of Atmospheric Composition Change, Int. J. Remote Sens., 30, 3875-3886, https://doi.org/10.1080/01431160902821841, 2009.

Stolarski, R. S. and Cicerone, R. J.: Stratospheric chlorine: a possible sink for ozone, Can. J. Chem., 52, 1610-1615, https://doi.org/10.1139/v74-233, 1974. 
Tegtmeier, S., Hegglin, M. I., Anderson, J., Bourassa, A., Brohede, S., Degenstein, D., Froidevaux, L., Fuller, R., Funke, B., Gille, J., Jones, A., Kasai, Y., Krüger, K., Kyrölä, E., Lingenfelser, G., Lumpe, J., Nardi, B., Neu, J., Pendlebury, D., Remsberg, E., Rozanov, A., Smith, L., Toohey, M., Urban, J., von Clarmann, T., Walker, K. A., and Wang, R. H. J.: SPARC data initiative: a comparison of ozone climatologies from international satellite limb sounders, J. Geophys. Res., 118, 12229-12247, https://doi.org/10.1002/2013JD019877, 2013.

Toohey, M. and von Clarmann, T.: Climatologies from satellite measurements: the impact of orbital sampling on the standard error of the mean, Atmos. Meas. Tech., 6, 937-948, https://doi.org/10.5194/amt-6-937-2013, 2013.

Tummon, F., Hassler, B., Harris, N. R. P., Staehelin, J., Steinbrecht, W., Anderson, J., Bodeker, G. E., Bourassa, A., Davis, S. M., Degenstein, D., Frith, S. M., Froidevaux, L., Kyrölä, E., Laine, M., Long, C., Penckwitt, A. A., Sioris, C. E., Rosenlof, K. H., Roth, C., Wang, H.-J., and Wild, J.: Intercomparison of vertically resolved merged satellite ozone data sets: interannual variability and long-term trends, Atmos. Chem. Phys., 15, 3021-3043, https://doi.org/10.5194/acp-15-3021-2015, 2015.

Vigouroux, C., Blumenstock, T., Coffey, M., Errera, Q., García, O., Jones, N. B., Hannigan, J. W., Hase, F., Liley, B., Mahieu, E., Mellqvist, J., Notholt, J., Palm, M., Persson, G., Schneider, M., Servais, C., Smale, D., Thölix, L., and De Mazière, M.: Trends of ozone total columns and vertical distribution from FTIR observations at eight NDACC stations around the globe, Atmos. Chem. Phys., 15, 2915-2933, https://doi.org/10.5194/acp15-2915-2015, 2015.

Vyushin, D. I., Fioletov, V. E., and Shepherd, T. G.: Impact of longrange correlations on trend detection in total ozone, J. Geophys. Res., 112, D14307, https://doi.org/10.1029/2006JD008168, 2007.

Waters, J. W., Froidevaux, L., Harwood, R. S., Jarnot, R. F., Pickett, H. M., Read, W. G., Siegel, P. H., Cofield, R. E., Filipiak, M. J., Flower, D. A., Holden, J. R., Lau, G. K., Livesey, N. J., Manney, G. L., Pumphrey, H. C., Santee, M. L., Wu, D. L., Cuddy, D. T., Lay, R. R., Loo, M. S., Perun, V. S., Schwartz, M. J., Stek, P. C., Thurstans, R. P., Boyles, M. A., Chandra, K. M., Chavez, M. C., Chen, G.-S., Chudasama, B. V., Dodge, R., Fuller, R. A., Girard, M. A., Jiang, J. H., Jiang, Y., Knosp, B. W., LaBelle, R. C., Lam, J. C., Lee, K. A., Miller, D., Oswald, J. E., Patel, N. C., Pukala, D. M., Quintero, O., Scaff, D. M., Snyder, W. V., Tope, M. C., Wagner, P. A., and Walch, M. J.: The Earth observing system microwave limb sounder (EOS MLS) on the Aura Satellite, IEEE T. Geosci. Remote, 44, 1075-1092, https://doi.org/10.1109/TGRS.2006.873771, 2006.
Wild, J. D., Yang, S.-K., and Long C. S.: Ozone Profile Trends: An SBUV/2 Perspective, Quadrennial Ozone Symposium 2016, Edinburgh, 2-9 September 2016, QOS2016-133, available at: http://meetingorganizer.copernicus.org/QOS2016/ QOS2016-133.pdf, 2016.

WMO: Scientific Assessment of Ozone Depletion: 2006, Global Ozone Research and Monitoring Project-Report No. 50, WMO (World Meteorological Organization), Geneva, Switzerland, available at: https://www.esrl.noaa.gov/csd/assessments/ozone/, 2007.

WMO: Scientific Assessment of Ozone Depletion: 2010, Global Ozone Research and Monitoring Project-Report No. 52, WMO (World Meteorological Organization), Geneva, Switzerland, available at: https://www.esrl.noaa.gov/csd/assessments/ozone/, 2011.

WMO: Scientific Assessment of Ozone Depletion: 2014, Global Ozone Research and Monitoring Project-Report No. 55, WMO (World Meteorological Organization), Geneva, Switzerland, available at: https://www.esrl.noaa.gov/csd/assessments/ozone/, 2014.

Wolter, K. and Timlin, M. S.: El Niño/Southern Oscillation behaviour since 1871 as diagnosed in an extended multivariate ENSO index (MEI.ext), Int. J. Climatol., 31, 1074-1087, https://doi.org/10.1002/joc.2336, 2011.

Zanis, P., Maillard, E., Staehelin, J., Zerefos, C., Kosmidis, E., Tourpali, K., and Wohltmann, I.: On the turnaround of stratospheric ozone trends deduced from the reevaluated Umkehr record of Arosa, Switzerland, J. Geophys. Res., 111, D22307, https://doi.org/10.1029/2005JD006886, 2006. 